\title{
An Appraisal of a River Cargo Transport Project
}

\author{
Mandana Bahrami (Corresponding author) \\ Department of Banking and Finance Eastern Mediterranean University, Famagusta, Cyprus \\ Tel: +90-533-8876331 E-mail: mbahrami1981@gmail.com \\ Siroos Khadem \\ Deakin University, VIC 3216, Australia \\ E-mail: sirooskhadem@gmail.com \\ Omotola Awojobi \\ Department of Banking and Finance, Eastern Mediterranean University, Famagusta, Cyprus \\ E-mail:mcawojobi@yahoo.com
}

Received: 08-04- 2013

Accepted: 16-04- 2013

Published: 30-04- 2013

doi:10.7575/aiac.ijfas.v.1n.1p.18

URL: http://dx.doi.org/10.7575/aiac.ijfas.v.2n.1p.18

\begin{abstract}
This paper provides evidence for the strength of the comprehensive analysis as an analytical tool to help the decision makers to improve their investment and operational strategies for river transportation projects. To do so, a River Cargo Transportation Company (RCTC) in Brazil was introduced and an integrated financial, economic, distributive and risk analysis was conducted to test the viability of the project. The analysis consists of identifying related financial and economic risk variables and performing the sensitivity analysis of these variables. The evaluation model of this project was based on a cost-benefit analysis methodology and a random calculation in which risk analysis was performed using Monte Carlo simulation. This integrated analysis provided a range of outcomes that can reduce the risk of uncertainty and give more reliable results than estimating the expected net present value or internal rate of return.
\end{abstract}

Keywords: Financial analysis, economic analysis, stakeholder analysis, Monte Carlo Simulation, river cargo transportation.

\section{Introduction}

Traditionally, humans use water sources as a means of transportation, trade, and communication. Despite the technological development in other modes of transportation such as air, rail, and truck, waterway transportation is still one of the major approaches to shipping cargo worldwide. Obviously, using the waterway system, especially in countries such as Brazil that benefit from long rivers, would help to improve the economy by reducing the cost of transportation, which is crucial in the competitive goods market. As of today, despite the fact that Brazil benefits from the Amazon basin, which is one of the most extensive continental waterways and does not require heavy investment for water transportation utilities, river transportation is not so popular there, as only a small percentage of cargo transportation is carried out via waterway. Missing this opportunity has increased the cost of products in some regions because producers might have to send their products to seaports located in east coast in order to export them to other countries. Not only this would increase the price of products, but it also could reduce the product competitiveness in the national and international markets.

Transport companies need to have a clear image about the impact of implementation of the river cargo transportation on the betterment of the economy, society, as well as individual investors' financial gain. There are also different uncertain variables that could jeopardize the future performance of the project; these variables should be identified and their impacts on all beneficiaries should be also measured. The research on water transportation evaluation (e.g., Calolina et al., 2002; Cosata \& Parr Rosson, 2007; Fuller et al., 2002; Grant-Muller et al., 2001; Koning \& Ludema, 2000; Leleur, 2000; Micro et al., 2004; Mudova, 2009; 
Pearman et al., 2003; Peter Brett Associates, 2009; Sallin \& Leleur, 2011; Wilmsmeier et al., 2009) has reported that researchers identified different set of influential variables and also employed a number of criteria for testing the outcomes of projects. However, analysts need to identify a reliable method that can inform them whether using waterway, compared to other transportation systems, is a worthwhile approach to goods transportation; and project appraisal would be an effective and efficient analytical method to help them with their decision-making process.

For the ease of explanation of comprehensive appraisal, a River Cargo Transportation Company (RCTC) in Brazil is represented and an integrated financial, economic, and risk analysis is used to determine probable costs and benefits associated with the lifecycle of the project so that it can be adapted to any other type of project under similar conditions. Assessment of the feasibility and sustainability of a RCTC is conducted in three stages based on the integrated analysis used by Harberger and Jenkins (2002). In the first stage, the conventional financial analyses (e.g., NPV, IRR, ADSCR, and LLCR as explained in the next section) are performed to determine the financial performance and viability of the project. In the second stage, the economic analysis is conducted to determine the sustainability of the project and its possible impacts on society. In the final stage, a sensitivity analysis is performed on the financial and economic results of the project to identify the potential risk variables that make the future of the project's outcome uncertain.

This integrated analysis shows that financial and economic values of the inputs and outputs of the project are different and they have different impacts and implications for stakeholders (investors and society) affected by the project. Results of sensitivity analysis, the risk analysis by using Monte Carlo simulation indicate that the outputs of the project will emerge through changing the risky variables under circumstances. Taken together, the results of the three-stage integrated analysis suggest that investment projects should be assessed by analyzing financial, economic and risk aspects of the project and their possible impacts of all affected stakeholders including investors, sponsors, policymakers, regulators, banks and society. The remainder of the manuscript is organized as follow: The next section describes the project and its specifications. Section III discusses the integrated analysis of financial, economic, stakeholder and risk assessment. Results of integrated analysis are presented in Section IV and conclusions, implications, contributions and potential limitations are provided in Section V.

\section{The Project}

Brazil has two critical agricultural areas of soybean crop production, Cuiaba and Campo Grande, located in south west of the country. Currently, residents of these areas are supplied diesel oil by truck and pipeline, costing $101.00 \mathrm{R} \$ / \mathrm{m}^{3}$ and to export soybean, they use truck to transport it to Sao Paulo, which costs 51.000 $\mathrm{R} \$ /$ ton. The RCTC will transport wheat and diesel oil from Buenos Aires to Caceres city and bring back soybean from Caceres city to Buenos Aires via Parana River during the working life of project, which is fifteen years. The freight charges for diesel oil are $32.4 \mathrm{R} \$ / \mathrm{m}^{3}$ and $28 \mathrm{R} \$ / \mathrm{m}^{3}$ for barges and truck respectively. These charges for soybean are $10.9 \mathrm{R} \$ /$ ton and $7.3 \mathrm{R} \$ /$ ton for barges and truck respectively.

\subsection{Project Financing}

The total investment costs of the proposed project is $\mathrm{R} \$ 18,375,000$ that will be financed by $15 \%$ equity, with the total amount of $\mathrm{R} \$ 2,756,250$ and $85 \%$ subsidized loan provided by the National Bank for Economic and Social Development of Brazil, with the total amount of $\mathrm{R} \$ 15,618,750$. The loan has a strategic advantage bearing a low interest rate of $4 \%$ with a 10 -year repayment period, and a one-year grace period after the construction is completed.

\subsection{Investment Cost}

The cost benefit analysis starts by estimating all investment costs of the project, which are crucial for an accurate analysis of investment costs. The project needs the following capital investments: 30 Barges for grain, 12 Barges for diesel oil and another 3 for Push boats. It takes 12 months to build the barges, push boats, offices and workshop facilities totaling $\mathrm{R} \$ 18,375,000$. It is assumed that the three convoys will be sold as scrap at the end of the project life. 
After the estimation of construction costs is done, the annual number of trips downstream and upstream and its revenue should be taken into account. The project has 36 trips per annum downstream and upstream. The revenue and the number of each trip are as follows:

- 10 barges of soybean are carried in each trip downstream. The load of each barge is 2.5 tones, and its freight revenue is $10.9 \mathrm{R} \$ /$ ton.

- 4 barges of wheat are carried with 2.5 ton per barge and 4 barges of diesel oil with $4.5 \mathrm{~m}^{3} / \mathrm{barge}$ in upstream trips. The freight revenue for wheat is $10.9 \mathrm{R} \$ /$ ton and for diesel oil is $\mathrm{R} \$ 32.4 / \mathrm{m}^{3}$.

Additional operating costs such as labor wages; maintenance and repair, fuel, port expenditure and insurance are also being taken into consideration. All the mentioned costs and benefits, which are required for construction of cash flow statement, will be recorded in table of parameters.

\subsection{Revenue}

The revenue of this project comes from the freight of soybean upstream, wheat and diesel oil downstream. As this revenue increases, the profitability of project increases. Table 1 illustrates the net revenue statement of the project.

Table 1: Net Revenue Statement (R\$ thousands)

\begin{tabular}{llll}
\hline Year & $\mathbf{1}$ & $\mathbf{2}$ & $\mathbf{3 - 1 5}$ \\
\hline Freight Revenue: & & & \\
Soybean & 4905.0 & 7357.5 & 9810.0 \\
Wheat & 1962.0 & 2943.0 & 3924.0 \\
Diesel Oil & 10497.6 & 15746.4 & 20995.2 \\
Service Tax & 868.2 & 1302.3 & 1736.5 \\
\hline Total Revenue (R\$ thousands) & $\mathbf{1 8 2 3 2 . 8}$ & $\mathbf{2 7 3 4 9 . 2}$ & $\mathbf{3 6 4 6 5 . 7}$ \\
\hline
\end{tabular}

This project was supposed to start in year zero. Startup costs in year zero totaled $\mathrm{R} \$ 18,375$ and is projected to generate revenue in year 1 . They will generate $\mathrm{R} \$ 18,232.8$ revenue in the first year of operation, working with $50 \%$ of its capacity, $\mathrm{R} \$ 27,349.2$ revenue in second year, working with $75 \%$ of its full capacity and $\mathrm{R} \$ 36,465.7$ revenue from the third year onwards.

\section{The Integrated Analysis}

\subsection{Financial Analysis}

The project owners and operators tend to invest in the financial strength of the enterprise and its ability to generate a sufficient return on investment (Jenkins, 2002). This can be assessed by the financial analysis of project that enables different parties involved in the financing of the project to evaluate its financial performance and viability; they can achieve this goal by evaluating the amount of revenues and costs as well as the future net cash flow that project will generate. Simply, financial analysis can show how much the owner will earn from the net cash flow of the future performance of the project after deducing their initial investment costs. It measures the change in their wealth created by the project and indicates the strength of the project to repay its debt obligation during its lifetime.

Financial analysis of the project will assess from two different viewpoints: bankers and owners' perspectives. Bankers want to know whether the project is able to pay the loan repayment from the cash generating of the project without the loan financing. All the revenues obtained during the operation of the project and expenditures spent on making these revenues will be counted. In other words, they do not include inflow of granting loan and outflow of loan repayment in their analysis. Then the Annual Debt Service Coverage Ratio (ADSCR) and Loan Life Coverage Ratio (LLCR) will be determined to inform creditors concerning the adequacy of the net cash flow of the project for different loan levels and terms of loans.

On the other hand, owners of the project consider any loan or grant as cash inflows, loan repayments and interest expenses as outflows along with the financing arrangement to appraise the financial viability of the 
project during its lifetime. They are interested to know the amount of revenue that the project generates and the amount of benefit they gain above their debt service obligations. This requires them to develop the cash flow statement as the central piece of financial appraisal. Then the net present value (NPV) is calculated to show the projected amount of annual net cash flow for the project. The higher the NPV, the more amounts of net cash flow for equity holders and the more profitable the project will be for them. Another means of assessment is internal rate of return (IRR), which shows the rate of return investors gain after recovering their invested capital; the IRR higher than discount rate is desirable for investors.

\subsection{Economic and Stakeholder Analysis}

After evaluating the project from investors' perspective, economic analysis is carried out to assess the impact of undertaking the project on the entire society and to determine if the public resources are distributed in the best way. For the purpose of economic appraisal, the true values of resources used or benefits generated for the economy should be identified. In reality, market prices are distorted even by the inefficiency of the market or by distortions such as taxes, tariffs, subsidies, import duties and excise taxes, which have prevailed impact on project and made the financial prices of each item of cost and benefit different from that of economic prices. In order to carry out economic analysis, the economic cash flow statement should be conducted in which the financial values of inputs and outputs are adjusted to their economic values by employing conversion factors (CFs). Then based on the economic cash flow statement, the economic NPV of project will be calculated by using economic discount rate.

\subsection{Stakeholder Impact Assessment}

Traditional method of cost benefit analysis undertook the financial and economic analysis, leaving the interaction of the financial and economic outcomes to some extent unidentified. However, there is difference between financial and economic values, called externalities, which is a source of benefit (or lost) for different groups, organizations or individuals such as consumers, government and labor forces affected by the project. These differences show the benefit or cost of other beneficiaries of the project apart from its sponsors. The distributive analysis will be employed to analyze the allocation of these externalities to various parties through the life of project and to examine how the setting up of the project will affect them. For the river cargo transportation project, two groups of stakeholders, who will be affected by carrying out this project, are identified: government and labor. There are also other affected groups such as the transporters, residents of cities where the project is executed, producers of beans and other labor forces who are indirectly involved in the execution of the project.

\subsection{Sensitivity and Risk Analysis}

The last step of integrated analysis is risk analysis of the financial and economic results of the project conducted to identify the risky variables that make the future of the project outcomes uncertain. The future uncertainty can have an influence on the outcomes of the project. The costs, prices and quantities that we estimate are rarely certain; they are connected to various outcomes, which could make the project risky. By doing sensitivity analysis, risky variables that have crucial impact on the project outcomes are identified and the impact of the change in variables is considered. This needs to account for the effects of "aggregate costs and benefits", "critical cost and benefit items" and "the effect of delay" on the outcomes of the project. There is some shortcoming associated with sensitivity analysis such as testing one variable in each time, ignoring the probability of happening of the events and correlation between variables. In order to overcome these shortcomings, Monte Carlo simulation is employed to calculate the range of possible outcomes; this needs to specify the probability distribution of the risky variables, which emerged from sensitivity analysis, as well as the correlation between different components. Running the program gives a set of results on the NPVs of the project on the continuum of worst to best scenarios. The outcomes can be analyzed by a set of statistics such as mean value, minimum and maximum values, standard deviation and variance.

\section{Results}




\subsubsection{Total Investment (Bankers') Perspective}

As explained before, Bankers use the ADSCR and the LLCR criteria to assess the financial sustainability of the project to be assure the project is able to repay the debt obligations from its operating income. After conducting financial statement of the project, it is time to extract relative ratios that help investors and creditors for their decision-making policy regarding the future performance of the project; this will include the approach they want to take to finance and the amount of financing the project. The proposed project will be financed by a low interest rate loan, which should be paid during a 10-years period, after a one-year grace period the project pays its loan interest. The result of calculating ADSCR and LLCR are summarized in Table 1 as follows:

Table 1: The ADSCR and LLCR Ratios

\begin{tabular}{lllllllllll}
\hline Year & 1 & 2 & 3 & 4 & 5 & 6 & 7 & 8 & 9 & 10 \\
\hline ADSCR & 1.1 & 1.0 & 1.4 & 1.3 & 1.5 & 1.8 & 2.0 & 2.5 & 2.6 & 3.1 \\
LLCR & 1.5 & 1.6 & 1.8 & 1.9 & 2.0 & 2.3 & 2.5 & 2.7 & 2.9 & 3.1 \\
\hline
\end{tabular}

As 1.5 is considered to be the benchmark for the ADSCR, it seems that project may have difficulty for its debt repayments. The results indicate that during the first four years, the ADSCR is not strong enough to guarantee lenders for receiving the principals and interests of their loan. However, from the fifth year the project will have a financial stability to be able to meet its obligation from its operating income without difficulty. Moreover, the LLCR indicates that the project might be able to meet its obligations by its future cash flows.

The reason for having low ADSCR and LLCR is that the fuel cost of this project is high and the duration of cost repayment, which shows by account payable, is around 15 days. This reduces the liquidity of the project from banker's point of view because they need higher cash flow after the project repays all operating costs. Moreover, the debt/equity ratio of the project is high, $85 \%$, and project owners have to pay more debt service in each year; consequently, it increases cash outflow and reduces the ADSCR and LLCR ratios.

\subsubsection{Equity Holder (Owners') Perspective}

Investors use NPV of net cash flow after financing in order to identify the amount of earning from the net cash flow of the future performance of the project when their initial investment cost is deducted. Using $15 \%$ discount rate shows that the proposed project will generate R \$ 4,294 NPV. This NPV shows that the project could generate enough cash flow to make a good return for their investors after paying its debt obligations. Another criterion for evaluating investment is IRR that shows the interest rate that makes NPV of cash flows equal to zero; the higher IRR shows the better return on investment and, therefore, the lower the risk of investment. In this analysis, IRR is equal to $35 \%$, which is higher than the real rate of return owners like to obtain from their investment.

Calculation shows that investment on this project makes sense for investors. The main point is that this project is highly leveraged; it means that the investment on this project is by debt that is less expensive than equity. Thus project would provide a high positive return for stakeholders and benefit the tax deductibility of financing, though the risk of bankruptcy should not be neglected. Sensitivity analysis will show how much this NPV is reliable.

\subsection{Economic Results}

Doing an economic analysis needs to calculate national economic parameters that has critical affect on financial values. The national economic parameters are assumed as foreign exchange premium FEP, $8 \%$ the economic opportunity cost of capital (EOCK), 12\%, the import tariff, $25 \%$, and the export tax, $5 \%$. The $5 \%$ service tax is levied on the freight prices. The actual income tax is equal to $25 \%$ in the base year, $33 \%$ in second year, $37 \%$ in third year and $34 \%$ from year four onward. 
In order to remove distortions from all benefits and costs items and adjust them to economic prices, the conversion factor should be calculated. The formula below shows the algebraic calculation of the conversion factor:

$$
\mathrm{CF}_{\mathrm{i}}=\frac{\text { Economic Value }}{\text { Financial Price }}
$$

The explanation of calculation of CF for different items is given below:

\subsubsection{Economic Opportunity Cost of Labor (EOCL)}

The economic opportunity cost of labor (EOCL) shows the occasion of using labor for one project on alternative market. In other words, the Economic Opportunity Cost of Labor (EOCL) is the value to the economy of activities given up by workers including non-market costs (benefits) associated with the change in employment (Harberger, et al 2010).

The proposed project is classified into two different categories of employees: skilled officers and managers and unskilled sailors and deckhands. The EOCL for unskilled labor is equal to supply price (EOCL $=\mathrm{Ws}$ ). The unskilled employees are not supposed to pay tax. It is considered that the skilled labors migrate from other regions to the project. However, to calculate the EOCL for the skilled labor the following formula is used:

$$
\mathrm{EOCL}=\mathrm{W}_{\mathrm{g}}^{\mathrm{S}}(1-\mathrm{T})+\mathrm{H}_{\mathrm{d}} \mathrm{W}_{\mathrm{a}} \mathrm{T}
$$

In which $\mathrm{W}_{\mathrm{g}}^{\mathrm{S}}$ is the supply price of the project, $\mathrm{W}_{\mathrm{a}}$ is the gross-of-tax wage of labor from alternative sources, $\mathrm{H}_{\mathrm{d}}$ is reduced demand for workers elsewhere, and $\mathrm{T}$ is the income tax rate levied on workers in all regions.

Based on the above formula, the EOCL for the skilled labor is equal to R $\$ 36,230$ and for the unskilled labor is equal to $\mathrm{R} \$ 9,160$. The financial value for evaluating conversion factor is considered as the labor's annual salary. The economic conversion factor for the skilled labor is equal to 0.852 and 0.784 for the unskilled labor. Since the economic conversion factor of this project for both the skilled and unskilled labor is less than 1 , this project has more benefit for the economy than employees.

\subsubsection{Economic Conversion Factor for Tradable Outputs}

For all tradable goods additional non-tradable services such as transportation costs and handling charges are imposed that distort the market. Thus, by calculating conversion factor for tradable outputs these distortions will be removed from the market prices and the values will be adjusted in economic prices. In this point, the economic price of exportable outputs is in hand. The conversion factor for exportable outputs is calculated as follows:

$$
\mathrm{CF}=\sum\left(\text { Share }_{\text {Item }} * \mathrm{CF}_{\text {Item }}\right)
$$

For the proposed project, steel, wood, cement and machinery are considered as exportable outputs that are used as inputs by the project and freight revenue of soybean, wheat and diesel oil as exportable output. 30\% of handling price and $80 \%$ of freight price is taken into account as tradable. Adjusting the FEP, handling and freight price with financial price, the economic value and conversion factor for each item is in hand. The economic value and conversion factor of all exportable components are given as follows:

Table 2: Conversion Factors

\begin{tabular}{lc}
\hline Item & Conversion Factor \\
\hline Freight Revenue & \multicolumn{1}{c}{$\mathbf{1 . 0 8 5}$} \\
components: & \\
$\quad$ Soybean & 1.085 \\
$\quad$ Wheat & 1.085 \\
$\quad$ Diesel Oil & 1.085
\end{tabular}


components:

$\begin{array}{ll}\text { Bricks } & 0.90 \\ \text { Cement } & 1.37 \\ \text { Steel bar } & 1.08 \\ \text { Labor } & 0.78 \\ \text { Others } & 1.00\end{array}$

Barge and Boat

\section{Operating Expenses}

Components:

$\begin{array}{ll}\text { Labor, Skilled } & 0.85 \\ \text { Labor, Unskilled } & 0.78 \\ \text { Maintenance } & 0.94 \\ \text { Dry docking } & 0.94 \\ \text { Fuel(diesel) } & 0.98 \\ \text { Port expense } & 0.94 \\ \text { Insurance } & 1.08\end{array}$

The conversion factor for the residual value of the assets of the project is the same as their related investment costs of assets.

\subsubsection{Economic Conversion Factor for Non-Tradable Outputs}

Like tradable components, distortions should be adjusted to non-tradable components. In this case, sand and brick are assumed as non-tradable. The economic value of these components can be approximated by formula below:

$$
\text { Economic Value }=\mathrm{Wd} * \mathrm{Pd}+\mathrm{Ws} * \mathrm{Ps}
$$

The weight of demand and supply for brick is considered as 0.33 and 0.67 respectively. By considering $\mathrm{R} \$ 33.93$ as a demand price and $\mathrm{R} \$ 29$ as a supply price of brick, the economic value of brick is $\mathrm{R} \$ 30.63$ and, consequently, the conversion factor of brick is 0.90 . On the other hand, the weight of demand for sand is 0.38 , weight of supply is 0.62 , the demand price is $R \$ 35.1$ and the supply price is $R \$ 30$ resulting in the economic value of $\mathrm{R} \$ 31.94$ and conversion factor of 0.91 .

\subsubsection{Other Conversion Factors}

Items such as land and change in cash balance have conversion factor equal to 1 because there is not any existing distortion on them. Conversion factor for changing in receivable account is assigned with the same conversion factor of the freight revenue, which is 1.08 in this project. The conversion factor for account payable is considered as the sum of the share of conversion factor of the corresponding operating expenses items except for labor. The calculation is pronounced in the formula:

$$
\mathrm{CF}=\sum \text { Share } * \mathrm{CF} \text { of the related operating cost }
$$

The conversion factor for account payable is equal to 0.98 .

Comparing the economic inflow and financial inflow of the project, the economic inflow of project is higher because CFs of the economic revenue is greater than one. On the other hand, almost all of the outflow items have conversion factor less than one. Implying the costs of the project is less for the economy than for the owner. Using the economic opportunity cost of capital as a discount rate, the economic NPV of project is calculated. In this case, the economic NPV of the project will be equal to R $\$ 28,884.7$ if $12 \%$ EOCK is used. 
The proposed project is located in Brazil and freight is carried out by barges to Argentina. Both countries, then, have to use different currencies during this transaction. The exchange rate between the countries is considered to be 1 . There are some distortions that make using foreign currency costly for economy. For the purpose of economic analysis, these distortions should be removed and economic exchange rate $\left(\mathrm{E}^{\mathrm{e}}\right)$ be used rather than market exchange rate $\left(\mathrm{E}^{\mathrm{m}}\right)$. Using $\mathrm{E}^{\mathrm{e}}$ removes distortion and adjusts $\mathrm{E}^{\mathrm{m}}$ to $\mathrm{E}^{\mathrm{e}}$. FEP is calculated as:

$\mathrm{FEP}=($ Tariff Revenue + Export Subsidies - export Taxes) / (value of Import + Value of Export)

Analysts use FEP to calculate the economic conversion factors of tradable and non-tradable sectors. The FEP for this project is calculated as $8 \%$.

\subsection{Stakeholder Analysis Results}

Stakeholder analysis helps the analysts to identify the beneficiaries and the amount of the benefit they make if the project is undertaken. One of the beneficiary groups of the project are the employees, who benefit from higher wages paid by the project compared with the alternative labor market wages. The total labor externalities for the proposed project is equal to $\mathrm{R} \$-1,137$.

The government externalities emerge from revenues and costs. In this case the government benefit is equal to $\mathrm{R} \$ 26,669$. The government will collect tax revenue on freight services of $\mathrm{R} \$ 16,964.2, \mathrm{R} \$ 1,293.6$ on investment costs, $R \$ 4,238$ on operating costs, and $R \$ 4,210.9$ on income taxes.

\subsection{Sensitivity and Risk Analysis Results}

The results of "what if" analysis shows that the project outcomes are sensitive to change in cost overrun factor, fuel price, freight price of soybean, wheat and diesel oil as well as the number of trips for soybean, wheat and diesel oil. A small fluctuation in each of these factors has a great impact on the outcomes of the project. If this change rises in cost items, more resources should be used in order to run the project and, consequently, the NPV of the project would decline. Costs and outcomes of the project are negatively correlated while this correlation between freight prices and outcomes is positive. As explained before, in order to overcome the shortcomings of the sensitivity analysis, the risk analysis is performed.

For the RCTC, the probability distribution for cost overrun factor is a step with a minimum value of $0 \%$ and maximum value of $50 \%$ with the higher probability of occurring between the range of 0 to $40 \%$. This distribution for number of trips of soybean, wheat and diesel oil is also a step with the range of change from 32 to 42 for all. Furthermore, the probability distribution for fuel price in this project is normal with the mean of 24 and standard deviation of 2.4 in the base case. Likewise, its freight price of soybean and wheat has a normal distribution has the mean of 10.9 and standard deviation of 1.38 in the base case for both prices. Diesel oil also has normal distribution with mean of 32.4 and standard deviation of 3.24. The results indicated that in the proposed project the fuel price is $95 \%$ correlated with the freight prices.

Figure 2 shows the cumulative distributive function of the financial NPV of the project. The distribution demonstrates the results from the lowest to the highest value after 10000 times running the simulation. The minimum value will be achieved if all negative condition happened. However, this process will be the other way around for the maximum value so that it will be fulfilled provided that all positive conditions are met. Figure 2 also indicates that it is $27.3 \%$ probable that the project has negative financial NPV which means the owner of project will face with a high level of risk of failure. The financial NPV of project is changed from minimum value of $\mathrm{R} \$-21,220.8$ to maximum value of $\mathrm{R} \$ 29,042.9$. The deviation from the expected value of the financial NPV is R $\$ 6,723.6$, which is higher than mean value and makes the estimation risky. The derivative results are shown in Figure 2 below: 


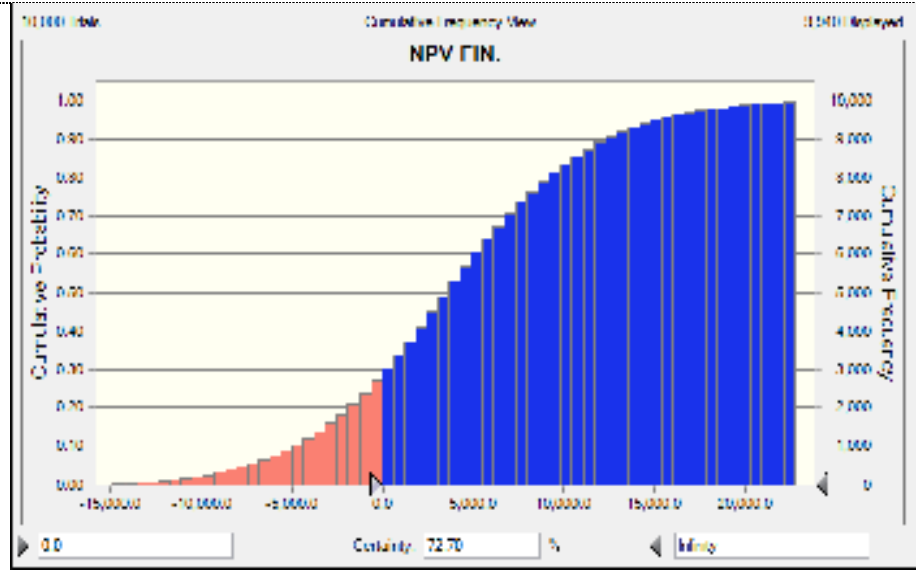

Figure 1: Cumulative Distribution of Financial NPV

Table 3 statistically shows the summary of risk analysis of NPVs and the probability of NPVs higher than zero.

Table 3: Summary of Risk Analysis Results of NPVs

\begin{tabular}{llll}
\hline Items & Financial NPV & Economic NPV & $\begin{array}{l}\text { Externalities } \\
\text { NPV }\end{array}$ \\
\hline Expected NPV(R\$ thousands) & $4,294.0$ & $28,884.7$ & $27,816.0$ \\
Standard Deviation & $6,723.6$ & $12,901.1$ & $5,377.4$ \\
Minimum Value & $-21,220.8$ & $-11,555.6$ & $15,328.4$ \\
Maximum Value & $29,042.9$ & $80,872.5$ & $50,747.7$ \\
Probability of NPV>0 & $72.70 \%$ & $99.61 \%$ & $100 \%$ \\
\hline
\end{tabular}

The economic results indicate that the likelihood of negative economic NPV is almost zero. The range of change in economic NPV is from R\$ $-11,555.6$ while the NPV is in its lowest value to R $\$ 80,872.5$ when $\mathrm{NPV}$ is in its highest value. It means that this project is economically viable in all ranges.

The Externality analysis results imply that the river cargo transportation project has benefit for other beneficiaries in all scenarios. In the worst case they expect to earn minimum benefit equal to $\mathrm{R} \$ 15,328$ thousand and in the best case their expectation will be $\mathrm{R} \$ 50,747$ thousand.

With regard to assessing the viability of project to the strength of debt repayment from year 1 to year 4 , project has ADSCR less than benchmark, 1.5. The results of risk analysis are as follows:

Table 4: Summary of Risk Analysis Results of ADSCRs

\begin{tabular}{llllll}
\hline Items & ADSCR & ADSCR Year & ADSCR Year & ADSCR Year & LLCR Year \\
& Year 1 & 2 & 3 & 4 & 1 \\
\hline Expected Value & 1.1 & 1.0 & 1.4 & 1.3 & 1.5 \\
Standard Deviation & 0.4 & 0.4 & 0.5 & 0.5 & 0.6 \\
Minimum Value & -0.3 & -0.3 & -0.3 & -0.5 & -0.5 \\
Maximum Value & 2.8 & 2.7 & 4.0 & 3.7 & 4.3 \\
Probability of $>1$ & $74.32 \%$ & $74.76 \%$ & $90.96 \%$ & $87.97 \%$ & $92.13 \%$ \\
\hline
\end{tabular}

The results indicate the high level of probability of failure in debt repayment by changing in the basic scenario in the first four years. Therefore, from bankers' point of view this project is subject to the high level of risk of failure.

\section{Conclusion}

Neglecting comprehensive investment appraisal, which synthetically considers a vast range of variables in different scenarios from the worst to the best case, might misguide the decision making process. The 
application of cost benefit analysis based on the integrated investment appraisal model designed by Harberger and Jenkins (2002) on RCTC indicates that although this project helps to enhance the wellbeing of the society and benefits the third parties, it needs some revision in order to be more attractive for investors and creditors. For example, this project is highly leveraged, which makes it risky for both owners and bankers. From the owners' perspective, despite the fact that project is subject to generating financial NPV equal to $\mathrm{R} \$ 4,294$, the outcomes are very sensitive to the small changes in price. As the results show, the probability of having negative financial NPV is $27.3 \%$. On the other hand, having a high level of leverage will put some restrictions on their investments, capital use and dividends in critical situations. The high debt to equity ratio is also vulnerable to the high level of insolvency, illiquidity and bankruptcy risk. The impact of the high debt to equity ratio also affects the bankers. From the bankers' perspective, the first issue is the key ratios that show the financial strength of the company as well as the availability of project to the repayment of its debt obligations. However, the results of risk analysis imply that the moderate variation in operating income can cause financial trouble for the project. The results of risk analysis shows that the likelihood of having ADSCR less than one in the first and second year of implementing the project is $74.32 \%$ and $74.76 \%$ respectively. This can pose a significant risk especially if a firm forecasts future sales incorrectly.

The economic analysis results also indicate that undertaking the project will generate net economic benefit equal to $\mathrm{R} \$ 28,884.7$ for the whole society. The distribution analysis results imply that benefit will be shared between the government, $\mathrm{R} \$ 26,857.1$, and other externalities such as labors, $\mathrm{R} \$ 2,027.6$. Therefore, based on the results of the integrated analysis, establishing the River Cargo Transportation Company under the present financing structure is not recommended. However, it will make sense for financial institution and the sponsors of the project to revise the financing structure and use a healthy capital structure that reflects a low level of debt and a corresponding high level of equity to mitigate the risk of uncertainty of debt repayment. They also need to embed some risk management strategies associated with mitigating the risk of price volatility based on future objectives and the performance of the project.

\section{References}

Akalu, M. \& Turner, R. (2001). Investment Appraisal Process: A Case of Chemical Companie. Retrieved from http://repub.eur.nl/res/pub/141/erimrs20020109141842.pdf

Bahrami, M. (2011). Investment Appraisal of a River Cargo Transportation Company in Brazil. Unpublished master's thesis, Eastern Mediterranean University.

Belli, P., Anderson, J., Barnum, H., Dixon, J., \& Tan, J.P. (1998). Handbook on Economic Analysis of Investment Operations. Operational Core Services Network, Learning and Leadership Center / World Bank, Washington, DC.

Belli. P. et al. (2001). Economic Analysis of Investment Operations: Analytical Tools and Practical Applications. The World Bank Washington, D.C.

Chang, J. J. Al-Hassan, A., Muhlbauer, E.N.P. (1997). River Transportation Company. Retrieved from Harward Business School, Institute for International Development.

Costa, R. F. \& Parr Rosson, C. (2007). Improving Transportation Infrastructure in Brazil: An Analysis Using Spatial Equilibrium Model on the World Soybean Market.

Caixeta-Filho, J. V. (2003). Transportation and Logistics in Brazilian Agriculture. Paper Presented at the Panel "Brazil: Competition in Global Markets" of the Agricultural Outlook Forum, Santos.

Economy of Brazil. (n.d). Retrieved from http://en.wikipedia.org/wiki/Economy_of_Brazil

Fuller, S. et al. (2002). Transportation Developments in South America and Their Affect on International Agricultural Competitiveness. A1B55-Agricultural Transportation Task Force. Retrieved from www.ltrc.lsu.edu/TRB_82/TRB2003-000883.pdf 
Grant-Muller, S., Mackie, P. Nellthorp, J. \& Pearman, A. (2001). Economic appraisal of European transport projects - The state of the art revisited, Transport Reviews, Vol. 21, No. 2, pp 237-261.

Harberger, A.C. \& Jenkins, G.P. (2010). Cost-Benefit Analysis of Investment Decisions: Queens University, Canada.

Jenkins, G, P. \& Klevchuk, A. (2002). Investment Appraisal of an Animal Feed Plant in South Africa, Cambridge Resource International Inc. $\quad$ Retrieved from http://econpapers.repec.org/paper/qeddpaper/163.htm

Jenkins, G. et al. (2004). Project Evaluation Criteria; Integrated Investment Appraisal: concept and practice. Cambridge Resources International, Inc. Cambridge, MA, USA.

Jenkins, G., et al. (2004). The Integrated Analysis, Integrated Investment Appraisal: concept and practice. Cambridge Resources International, Inc. Cambridge, MA, USA.

Leleur, S. (2000). Road Infrastructure Planning - A Decision-Oriented Approach. 2n Edition, Lyngby: Polyteknisk Press, Denmark.

Pearman, A, Mackie, P. and Nellthorp, J. (eds.) (2003). Transport Projects, Programmes and Policies: Evaluation Needs and Capabilities. Aldershot, Ashgate.

Piermartini, Roberta. (2004). The Role of Export Taxes in the Field of Primary Commodities. Geneva, Switzerland: ERSD, WTO.

Randall, S, Dohlman, E. \& Christine, B. (2001). Agriculture in Brazil and Argentina: Developments and Prospects for Major Field Crops. Agriculture and Trade Report, No. 85, WRS013, ERS, USDA.

Savvides, S. C. (1994). Risk Analysis in Investment Appraisal. Project Appraisal, Beach Tree Publishing.

Salin, D.L. \& Ladd. J. E. (2009). Soybean Transportation Guide: Brazil 2008, United States Department of Agriculture-USDA, Agricultural Marketing Service Retrieved 18 February 2011, from http://www.ams.usda.gov/AMSv1.0/getfile?dDocName=STELPRDC5079555

Salling, K. B. \& Leleur, S. (2006). Assessment of Transport Appraisal by the use of Monte Carlo simulation: the CBA-DK model. Proceedings of WSC '06, Monterey, CA-USA.

Salling, K. B. \& Leleur, S. (2010). Transport appraisal and Monte Carlo simulation by use of the CBA-DK model - ISSN 1567-7141, 103-120. Retrieved 12 January 2011, from http://www.ejtir.tudelft.nl/issues/2010_01/pdf/2010_01_08.pdf

Sarabia, María Carolina, Ríos, John H., Paternina-Arboleda, Carlos D. (2002). Simulaton Based Decision Support models for River Cargo Rransportation. Retrieved 25 July, 2010, from http://www.sys.virginia.edu/sieds06/papers/FMorningSession7.3.pdf

World Bank. (2005). Risk \& Uncertainty Analysis, Transport Economics. Transport Note No. TRN-7, Policy and Poverty Thematic Group. Washington, D.C.

Central Bank of Brazil, Retrieved 20 July 2010, from http://www.bcb.gov.br/?english

IMF. (2010). IMF Financial Statistics Yearbook 2010. International Monetary Fund (IMF), Washington, D.C. 